\title{
Problem Based Learning (PBL): A Novel and Effective Tool of Teaching and Learning
}

\author{
Mohammed Tahir Ansari*, Santibuana Abd Rahman, Vishal Bhagwan Badgujar, Farheen Sami and \\ Mohd Syafiq Abdullah
}

Faculty of Pharmacy and Health Sciences, Universiti Kuala Lumpur-Royal College of Medicine Perak, Ipoh.

\begin{abstract}
Recently a surge has been witnessed in number of new academic pharmacy institution establishing concern with quality of graduates passing out. Survey has also established the poor understanding of the health education among the students. Developed countries have formulated and successfully implemented new strategies to impart education to the current generation. Problem Based Learning (PBL) is one of the novel technique used in majority of health universities in US, UK and Asian countries. This has led to tremendous development in the quality of health science graduates. The process allows a group of student to discuss and solve a real life situation though discussion. It involves exposing a group of students to a trigger/case/problem asking the student to solve the trigger within a specified time through a defined process facilitated by a tutor. The student are allowed to go for self-study based on their discussion and allowed to meet again for second session after a week to solve the trigger. The student capability can be measured by the facilitator using a designed rubrics or any other evaluation strategies. This process have proved to enhance the soft skill, cognitive, metacognitive, problem solving and critical thinking skills among the students. The strategy also helps the students to work in group and develop a democratic attitude and to judge a problem based on consensus. Indian pharmacy colleges should adopt the system to install critical thinking ability among the students.
\end{abstract}

Key words: Cognitive, Critical thinking, Facilitator, Problem Based Learning, Trigger.

\section{INTRODUCTION}

The last decade has witnessed a significant surge in new pharmacy academic establishment pan Asian nation including India, inflicting concern regarding low levels of skilled education among graduates. Several reasons can be cited like inadequate school, inadequate workplace facilities, ancient master and apprentice model and less hands on trainings. This could seriously replicate negatively on the standards of professional graduates. Traditional didactic lectures are teacher oriented, providing static information and cannot enhance the professional qualities of the scholars. Moreover, if the scholars are explored and examined on their critical parameters than the results will not be very encouraging. New and innovative methods have been explored to enhance the quality of graduates among the competitive world. Problem Based Learning (PBL) is one of the novel techniques which has been successfully implanted in majority of the health schools and colleges in developed countries. It has been defined as a learning method, a unique approach which uses real practice situation problems as a starting point working, as a stimulus or trigger for the acquisition and integration of new knowledge. ${ }^{1}$ A more accurate title for the technique has been suggested like "Student-centered, problem based, inquiry-based, integrated, collaborative, reiterative, learning". ${ }^{2-6}$

Problem based learning have been proved to be a success in the enhancement and development of critical thinking ability, leadership qualities, self-directed learning, professional and interpersonal skills, team working skills, management skills, collaborative learning,English speaking qualities, practicing empathy and many more. ${ }^{7-9}$
Submission Date : 11-03-2015 Revision Date : :23-04-2015 Accepted Date : 25-05-2015

DOI: 10.5530/ijper.49.4.3 Correspondence Address Mr Mohammed Tahir Ansari

Department of Pharmaceutical Sciences

Faculty of Pharmacy and Health Science

Universiti Kuala Lumpur Royal College of Medicine Perak, No.24, Lebuh Perusahaan Kelbang 1, IGB Industrial Park, Jalan Kuala Kangsar, Tasek, Ipoh 30010 Perak, Malaysia.

E-mail:md.a.tahir@gmail. com

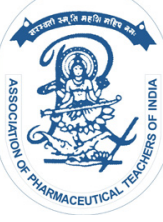

www.ijper.org 


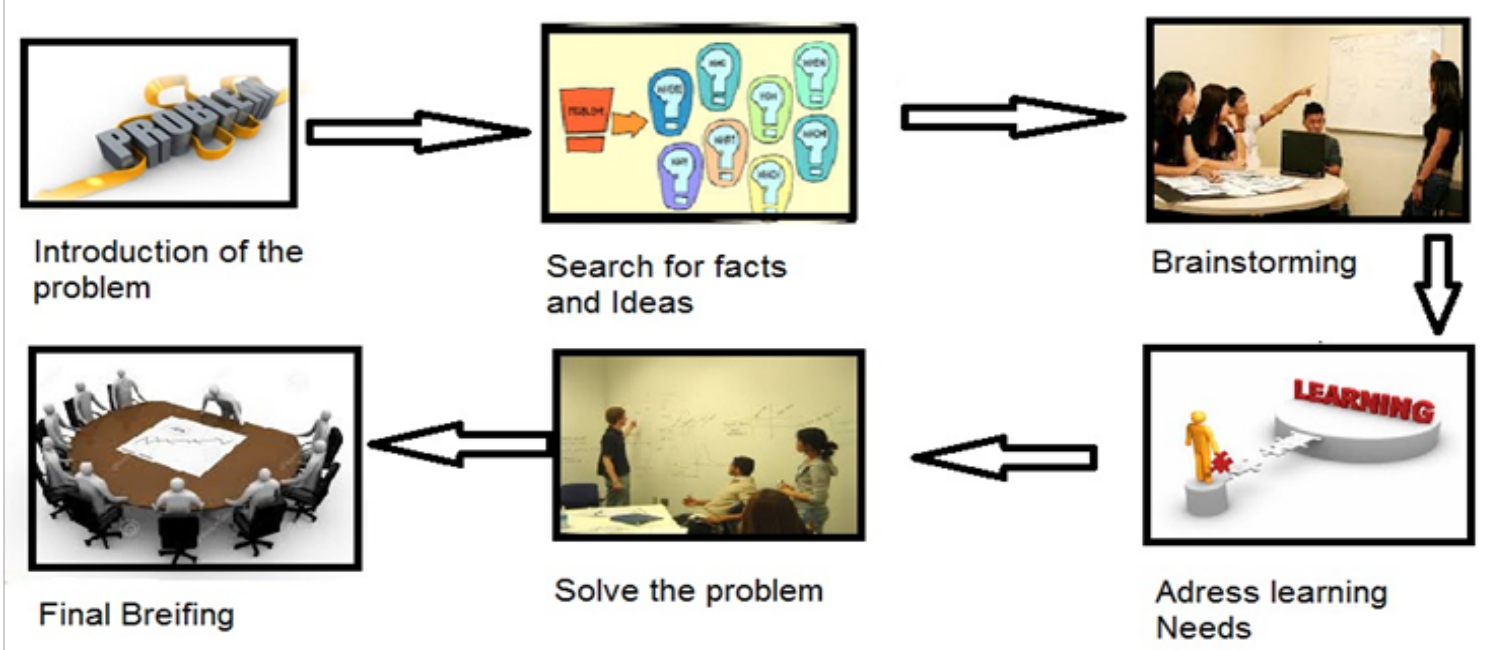

Problem based learning process

Pictorial Abstract

Literature has outlined the importance and effectiveness of PBL over the traditional method of teaching. A survey was conducted for graduates of 4 baccalaureate degrees respiratory therapy programs in the southeastern and south central United States to compare PBL with the traditional approach of teaching. The result envisaged substantial satisfaction of students exposed to PBL, which was additionally evident from student's performance in writing registered respiratory therapist examination. ${ }^{10}$ PBL implemented into the dental curriculum at the Harvard school of dental medicineshowed a significant improvement in communication with patients, critical thinking, independent learning and substantive improvement in small group settings, self-assessment and teamwork. ${ }^{11}$ A study was also conducted to compare the effect of PBL and lecture-based learning (LBL) on the satisfaction and learning progress among undergraduate midwifery students. The study resulted in a strong suggestion of implementing PBL in the curricula owing to its superlative student satisfaction and improved application of a theory lesson in clinical practice. ${ }^{12} \mathrm{PBL}$ is suggested as a constrictive studentcentered and problem-based novel teaching approach in medical education. ${ }^{13}$ It is geared to facilitate knowledge retention and application while fostering the skills desired in physicians, such as clinical reasoning, critical thinking and self directed learning. ${ }^{1}$ The PBL approach has been found to improve physician competency in the social and cognitive domains. ${ }^{14}$

Owing to its effectiveness many leading universities have integrated PBL in its curriculum. The University of New Mexico medical school offered a PBL curriculum as an alternative track. ${ }^{15}$ Over the last two decades, established schools like Harvard, ${ }^{16}$ UTM Malaysia, ${ }^{17} 12$ of 32 medical schools in $\mathrm{UK}^{18}$ have used PBL as teaching tool. According to a survey of 123 medical schools in the United States, $70 \%$ of the medical schools use PBL especially during the preclinical years. ${ }^{19}$ PBL pedagogy has been successfully implemented in medicine, $^{20-26}$ Dentistry, ${ }^{27-28}$ Nursing, ${ }^{29-32}$ Engineering, ${ }^{33-34}$ Pharmacy ${ }^{35-37}$ and Mathematics. ${ }^{38}$

\section{PBL PEDAGOGY AND REQUIREMENT}

\section{Facilitator}

The tutor/teacher should be a facilitator for PBL session. Barrows have claimed that the task of the tutor in a problem based tutorial group should be to facilitate the learning of students rather than to convey knowledge. ${ }^{1}$ It would not be necessary, but possibly beneficial if the facilitator knows the subject as PBL facilitator, he/ she may employ knowledge of the subject to support the processes of cognitive or metacognitive development and/or enculturation. The session can be assisted by playing a role of a learner by staying silent, creator by probing questionsdirect or by reflecting questions, evaluator by positing in the group and/or modeler by stimulating interest. ${ }^{39-40}$ It is required for the tutor to be impasse and laconic as much during the session. This is not an easy tutors vocation, but it is symbolic to cogent PBL pedagogy. It is apparent that tutors experienced in a traditional tutor centered concept of teaching with a subject based curriculum may find themselves under quagmire during a problem based pedagogy session.

The teacher's role is to facilitate collaborative knowledge construction. Studies have focussed on assessing goals of a facilitator. Primarily facilitator(s) should be capable 
of understanding less vocal students among the group and involvement of them in the discourse should be undertaken. The facilitator can and should change the flow of the discussion from being temporarily stalled to being more focused, so it can easethe learning process on track. The tutor/facilitator should also make the student's thoughts and their depth of understanding apparent and encourage students to become self-reliant for direction and information. ${ }^{41}$ It is envisaged and also supported by studies that PBL session should be facilitated by a tutor as priorities for tutorless groups differs as the concerning issues may be frustrated because not everyone appears to do their fair share of the work, attendance, building trust, reliability and personal differences in learning. ${ }^{42}$

A study to investigate the relevance of the background of the facilitator was done and it was evident that qualified clinical tutors classified better in establishing and maintaining an environment of cooperation within their PBL groups than non-clinical tutors in facilitating a group of medical students. ${ }^{43}$ Schmidt et al have also concluded that tutor/facilitator tutoring, skill and content knowledge seemed to be necessary and closely related conditions for effective tutoring. His analysis resulted in students guided by content experts in a PBL session achieved better scores and spent more time on self-led learning. ${ }^{44}$

\section{PBL student groups}

As defined earlier PBL is a student centered approach in which students learn about a subject by working in groups to solve an open ended problem. Group learning facilitates not only the acquisition of knowledge, but also several other desirable attributes such as communication skills, teamwork, problem solving, independent responsibility for learning, sharing information, and respect for others. PBL can therefore be thought of as a small group teaching method that combines the acquisition of knowledge with the development of generic skills and attitudes. ${ }^{25,45}$

The PBL group are briefly identified to facilitate the process of learning, fostering of self-directed learning initiatives, engaging lifelong learning qualities and developing social skills that may enhance professional relations. These goals may only be reached by systematic and proficient work with the group processes in PBL. ${ }^{46}$ Student's supports small PBL group work as a method of learning and those groups that work cooperatively are perceived as facilitating the most motivating learning environment. ${ }^{47}$ The students in the PBL class had more positive attitudes toward their learning environment on the subscales for enthusiasm and authoritarianism. The learners during the session themselves have to clarify their understanding and identify further learning needs which are considered important for formulating, synthesizing and evaluating knowledge. ${ }^{48-49}$

Students in the PBL group build up meta-cognitive skills and self-directed learning considered important for the student's development into independent, lifelong learners, responsible for their own learning. Schraw describes two aspects of metacognition that he claims are necessary for self-directed learning; the knowledge of cognition and the regulation of cognition. ${ }^{50}$ These skills are teachable, he argues, and emphasizes that instructional strategies should promote the construction and acquisition of meta-cognitive awareness. Self-directed learning comprises the ability to formulate learning goals, identify resources for learning, choose relevant and appropriate strategies for learning, and evaluate the learning outcomes..$^{51-52}$

PBL student groups are characterized by 5 or 9 individuals entrusted to work symbiotically and cooperativelyin a self-directed way on a delineated learning needs. The group should be characterized by a group leader/ chairperson supported by a scriber. The teams may be organized as vertical teams in which group leader/chairperson makes crucial decisions if the team is unable to reach a consensus or horizontal teams in which crucial decisions are made by majority vote. The dynamics of the group can be predefined or may be optimized based on the subjects or topics. ${ }^{53} \mathrm{PBL}$ students small groups attempt to resolve a real-life clinical problem by using their existing knowledge to generate hypotheses and then actively finding the cross-disciplinary knowledge they need to fully understand the problem. ${ }^{54}$ It is evenly conceivable that students who have significant deficiencies in critical thinking, speaking ability, decision making, leadership qualities are more likely to drop out of any institution of higher learning, but they are even more likely to be unsuccessful in a PBL program, which requires the ability to process and discuss ideas and learn independently. ${ }^{55-56}$

\section{Designing Triggers/Problems/Tasks}

PBL triggers are utilized to stimulate the student's interest in resolving the problem scenarios presented to them. Designing of PBL triggers/problems or task is very critical as badly designed trigger will not be able to cover the learning needs and the students discussion may go haywire. PBL triggers are integrated with the PBL problems, but the material is not taught in the same tutorials or by the tutors. PBL trigger should be conceptual and based on authors experience and literature studytriggers can be classified under the following three categories: 
- Open type trigger: The students know the subject and the topic to be covered in PBL session.

- Single blind type trigger: The students knows the subject but the topic to be discussed is unknown.

- Double blind type trigger: The students remains unknown for the subject and the topic of PBL session.

Student learning process through PBL is largely based on the quality of the cases / trigger presented to the students. Dolmans concluded that the following attributes are essential to formulate an effective trigger or a case for PBL. ${ }^{57}$

- Prior knowledge

- Elaboration

- Relevant context

- Integration of knowledge

- Self-directed learning

- Interest in the subject matter

- Faculty objectives

\section{PBL Session}

PBL delivery should be conducted in two sessions. Each session can be of 1-2 hrs. depending on the content and scope of the subject. Clinical subjects should not be covered in less than 2 hours per session.

\section{INTRODUCTORY SESSION 1}

This session should be characterized by the following features:

\section{Introduction}

In this session the group members will introduce and greet each other. They should be advised by the facilitator to choose among them the chairperson of the group for the session. It is important that everyone has a chance to be a chairperson and experience the challenge of leading a group. Accordingly the chairperson should be rotated between group members on a per-problem basis or per session. This means that each student should have the chance of being a chairperson at least once a term. The skills developed from chairing a group at this early stage ineducation could be invaluable. ${ }^{58}$ The Chairperson is responsible for agreeing group processes, introducing the case to the group, inviting participation and ensuring all members are contributing. They also ensure that all areas are covered and oversee timekeeping. In addition, it is their role to monitor and comment on performance at the end of the session and promote discussion regarding any problems. The session should extend for maximum of 10 minutes. ${ }^{59}$

\section{Clarification of terms}

Davis conducted a psychometric analysis to determine strategies and step for acquiring better comprehension skills, he listed nine potential component skills of comprehension word meanings, word meanings in context, follow passage organization, main thought, answers specific text-based questions, text-based questions with paraphrase, draw inferences about content, literary devices, author's purpose. ${ }^{60}$ This step should be integrated with PBL session as students need to associate visual patterns of letters with their phonemic pronunciations. The consequence may help the students decode progresses from hesitant, deliberate to fluent actions. ${ }^{61}$

The purpose of the first step is to agree on the meaning of the various words and terms and on the situation described in the problem. Use can be made of the knowledge possessed by the group members or retrieved from a dictionary. ${ }^{62}$ The process can effectively be extended for 10 to 15 minutes.

\section{Facts and ideas}

After the chairman is entrusted that the group has fully understood difficult terms and the context of it appearing in the problem or trigger, he should read the trigger loud and clear. Other members may repeat the process. Reading the trigger loud may carry specific advantages. It may help chairperson or the facilitator to diagnose dis-fluency and the lack of proficiency among the students and may also be a strategy promote the students to be active in the group. It is imperative for the group to read the trigger aloud specially among those for whom english is not the native language. ${ }^{63}$ Duursma have also suggested that reading aloud emphasizes better phonological awareness and comprehension of the subject. ${ }^{64}$

The group after better comprehension of the problem should visualize for facts and ideas in the trigger. Scriber should be asked to write down all the related ideas on the board for better understanding. If a PBL is conducted for a disease, then the group should be able to list all the symptoms leading to the disease in a

\begin{tabular}{|c|c|c|c|}
\hline Ideas & Facts & Learning Issues & Action Plan \\
\hline $\begin{array}{l}\text { Students conjectures } \\
\text { regardingthe problem or trigger } \\
\text { may involve causation effect, } \\
\text { possible resolution and so on. }\end{array}$ & $\begin{array}{l}\text { A growing synthesis of } \\
\text { information abstracted through } \\
\text { inquiry as important to the } \\
\text { hypothesis to be generated. }\end{array}$ & $\begin{array}{l}\text { Students list of what they need } \\
\text { to know or understand in order } \\
\text { to complete the problem task. }\end{array}$ & $\begin{array}{l}\text { Things that need to be done } \\
\text { in order to complete the } \\
\text { problem task. }\end{array}$ \\
\hline
\end{tabular}


patient. ${ }^{65}$ Duffy suggested a chart to negotiate a design for addressing an issue related to the trigger (Table 1). ${ }^{66}$

After the discussion and identifying signs and symptoms of the problem the students should be able to list the cues and key points. The process will certainly enhance the thinking ability and develop a positive problem solving approach. The session can be extended for 20 minutes.

\section{Brainstorming (Generation of hypotheses)}

This stage will help in activating existing knowledge to understand the phenomenon and promotes reasoning skills in generating an explanation (hypothesis). It involves active discussion and exchange of knowledge and information. It is important to ensure that all members of the group feel free and uninhibited to express themselves. The chairperson would lead the discussion with functional and non-functional questions related to the trigger. It should include an exhaustive discussion among the members to address the issue. The session should be actively assisted by the scriber to record all generated hypothesis during the process. ${ }^{67}$ The facilitator should discourage the group to generate hypothesis which cannot address the learning needs. ${ }^{65}$ The brainstorming session should be followed after creating certain facts for the research to achieve the best conclusion or else the result would not be as good. ${ }^{68-69}$ Since, student may come up with a variety of hypotheses during the session, the process may ventilate innovative practices and critical thinking ability. ${ }^{70}$

\section{Learning needs (Learning outcomes)}

Students are not exposed to the learning needs, but they are supposed to transform all the generated hypothesis into learning needs as desired by the syllabus. ${ }^{71}$ Theycan be simplified by raising some questions such as, If a trigger has been devoted to diabetes, the students should be able to ask.

What would be the physiological conditions of the body during diabetes?

What should be the treatment for diabetes?

What are the dos and don'ts for treating diabetes? ${ }^{72}$

The facilitator should be assertive in his approach to guide the students if required, as the students tend to diverge from the capturing learning needs. The role of facilitator is very important to assert that the students achieve the required outcome. The session may be extended for 10 minutes.

\section{Debriefing I}

After the completion of the session the facilitator must address the group about their outcome with compliments and encouraging remarks so as to infuse the habit of critical thinking and problem solving.
After completing session 1, students are responsible to do independent and self-directed learning. Students gather information and ideas from reliable sources. Use the full range of useful resources available, organize responses to each learning outcome, making summarized notes. They would be allowed to reassemble and discus their finding after a week in session 2 .

\section{CLOSING SESSION 2: DISCUSSION AND DEBRIEFING}

\section{Review of trigger}

After the students are allowed to go for self- directed learning using academic resources they are allowed to meet again for closing session (session 2) of PBL pedagogy. The students shall now be equipped with newly acquired knowledge, the group reconvenes to discuss the case. The discussion includes an explanation of the central concepts and mechanisms, analysis of the material and evaluation of its validity and importance. ${ }^{73}$ Theprocess may develop a democratic attitude among students and will also develop the decision making by consensus. ${ }^{74}$ This discussion is not a debate and it is not for the purpose of winning. Discussion during the PBL session is a skill that makes the thought processes visible, allows assumptions to surface and be challenged, and exposes the sources of disagreement. Effective discussion should focus on issues, not personalities. ${ }^{75}$ Facilitators must be careful not to interject their ideas, but rather, focus on promoting student interaction and discussion toward a decision. Tutors, for example, must be careful not to practice facilitation by manipulation. The facilitator may take a more passiverole in allowing the students to lead, but taking into cognizance the pathway of the discussion. The facilitator may help students where they lack information, but should be cautious in moving their team to their view point. ${ }^{76}$ It is imperative that PBL pedagogy will empirically inculcate the quality of leadership and management among the students as they would be allowed to lead a session. ${ }^{77}$ The sessionmay be extended for 80-90 minutes.

\section{Summary}

After the discussion has been done the chairman should summarize the data, valid points and cross check if the learning needs have been addressed effectively. The chairman may also consult among the group and once satisfied with the academic aspects should announce for the closure of the session.

\section{Debriefing II}

After the student chairman announces the closure of the session the facilitator should take charge and summarize the events in a constructive manner with mostly 
positive reflections of students to provide encouragement, interest, and they should also evaluate the session based on the learning needs accomplished. He should associate negative feedbacks for a student's very politely so that it doesn't discourage students in taking part in PBL. The debriefing should be highly motivating, especiallyin communication and presentation skills. Students should also be asked to give viewpoints in respect of their own performance and that of their peers. ${ }^{76,79,80}$

\section{Evaluation}

Many dimensions of PBL evaluation have been addressed in literature ${ }^{81}$ An effective assessment and evaluation program can insure that students are deriving the maximum benefits from PBL and the process is being conducted effectively for the given environment. Das et al have suggested the evaluation of students based on the following parameters using a Likert scale. ${ }^{82}$

- Responsibility

- Information processing

- Communication

- Critical Analysis

- Self awareness.

Rosemaria has also conducted a research on the evaluation criteria for evaluating students for PBL session. A 24 reliable identification fundamental component rating scale was developed to assess student performance during tutorial sessions in PBL. It proved to be effective and a conducive method to evaluate students. ${ }^{83}$ Process assessment which contains of self reflection, peer's evaluation and task completion reports allow to identify student progress and deficiencies and making them independent learners. ${ }^{84}$

\section{CONCLUSION}

PBL should be implemented to achieve critical thinking, scientific thinking, leadership qualities and managerial skills among students. The technique has already been a proven success in majority of the developed countries. The technique may prove to infuse the missing vital qualities to become a professional student. It should be tried and included specially subject dealing with disease and drugs to initiate vigorous thinking among students which may install all related information for a particular disease.

\section{ACKNOWLEDGEMENTS}

The authors would like to thank Faculty Members of Department of Pharmacy, UniKL-RCMP for their contribution in writing this article.

\section{CONFLICTS OF INTEREST}

To the best of our knowledge, no conflict of interest, financial or other, exists.

\section{ABBREVIATION USED}

PBL: Problem based learning

LBL: Lecture based learning

\section{SUMMARY}

- An innovative and a novel method for teaching and learning.

- It will enhance the cognitive, metacognitive, team spirit, soft skills of the students.

- Critical thinking and problem solving skills of the students are enhanced and students develop technique to address critical real life issues effectively.

\section{About Authors}

Mohammed Tahir Ansari: Presently working as an Assistant professor/Senior lecturer in the Department of Pharmaceutical Sciences, Faculty of Pharmacy and Health Sciences, Universiti Kuala Lumpur-Royal College of Medicine Perak, Ipoh, Malaysia. Ex-Faculty Amity University Uttar Pradesh, Lucknow and NIPER, Raebareli (UP). He has over 20 papers in journal of national and international repute.
Prof.Dr. Mohamad Syafiq Abdullah: Working as Dean, Faculty of Pharmacy and Health Sciences, Universiti Kuala Lumpur-Royal College of Medicine Perak, Ipoh, Malaysia. He is the one of the pioneer in introducing the PBL pedagogy in University Malaya, Malaysia. He has given many lecturers on the implementation of PBL.

\section{REFERENCES}

1. Barrows HS, Tamlyn RM. Problem-based learning: Rationale and definition. In: Problem based learning: an approach to medical education. $1^{\text {st }}$ Edition New York: Springer Publishing Company; 1980. 1-18.

2. Barrows HS. Problem based learning applied to medical education. $2^{\text {nd }}$ Edition. Southern Illinois University School of Medicine; 1999.

3. Knowles MS. The modern practice of adult education: From pedagogy to andragogy. $2^{\text {nd }}$ ed. Chicago: Follet; 1980.
4. Cleverley D. Implementing inquiry based learning in nursing. Routledge: London; 2003

5. Margetson D. What counts as problem based learning. Education health 1998; 11(2): 193-201.

6. Savin Baden M. Problem based learning in higher education: untold stories. Buckingham, UK: Society for Research in Higher Education/Open University Press; 2000. 
7. Dolmans $\mathrm{D}$, Schmidt $\mathrm{H}$. What directs self-directed learning in a problem based curriculum. In: Evensen D, Hmelo C, editors. Problem based learning: a research perspective on learning interactions. Mahwah, $\mathrm{NJ}$ : Lawrence Erlbaum; 2000. 251-62.

8. Woods DR. Problem based learning: helping your students gain the most from PBL. Hamilton, CA: DR. Woods; 1995.

9. Engel CE. Not just a method but a way of learning. In: Boud D, Feletti GP. Editors. The challenge of problem-based learning. London: Kogan Page; 1991. 22-33.

10. Beachey WD. A comparison of problem-based learning and traditional curricula in baccalaureate respiratory therapy education. Respiratory Care. 2007 Nov; 52(11): 1497-506.

11. Thammasitboon K, Sukotjo C, Howell H, Karimbux N. Problem-based learning at the Harvard school of dental medicine: self-assessment of performance in postdoctoral training. J Dent Educ. 2007 Aug; 71(8): 1080-9.

12. Gita S, Mahnaz K. Comparison of problem-based learning and lecture-based learning in midwifery. Nurse Education Today 2013; 33(8): 791-5.

13. Savery JR, Duffy TM. Problem based learning: an instructional model and its constructivist framework. In Constructivist learning environments: case studies in instructional design. Wilson BG, Editor. New Jersey: Educational Technology Publications 1996; 35(5): 135-50.

14. Koh GCH, Khoo HE, Wong ML, Koh D. The effects of problem-based learning during medical school on physician competency: a systematic review. CMAJ. 2008; 178(1): 34-41.

15. Donner RS, Bickley HB. Problem-based learning in American medical education: an overview. Bull Med Libr Assoc. 1993; 81(3): 294-8.

16. Elizabeth Armstrong G. A Hybrid Model of Problem-based Learning. In: Boud D. and Feletti G. Editors. The Challenge of Problem based Learning. $2^{\text {nd }}$ Ed. London: Kogan Page; 1997. 137-50.

17. Mohamad Termizi Borhan. Problem based learning (PBL) in malaysian higher education: a review of research on learners experience and issues of implementations. Asean journal of engineering education 2012; 1(1): 48-53.

18. McKendree J. Experiences of problem-based learning in the UK. Clin Teach. 2010; 7(4): 262-5

19. Kinkade S. A snapshot of the status of problem-based learning in U. S. medical schools, 2003-04. Acad Med. 2005; 80(3): 300-1

20. Bligh J. Problem-based learning in medicine: an introduction. Postgrad Med J. 1995; 71(836): 323-6.

21. Gerald CHK, Hoon EK, MeeLian W, David K. The effects of problem-based learning during medical school on physician competency: a systematic review. CMAJ. 2008; 178(1): 34-41.

22. Schmidt HG, Vermeulen L, Van der Molen HT. Long term effects of problembased learning: a comparison of competencies acquired by graduates of a problem-based and a conventional medical school. Med Educ. 2006; 40(6): 562-7.

23. Xiaojie Ding et al. Assessing the effectiveness of problem-based learning of preventive medicine education in china. Scientific Reports 4 , Article number: 5126, 2004.

24. Cindy Hmelo E, GeraldGotterer S, John Bransford D. A theory-driven approach to assessing the cognitive effects of PBL. Instructional Science 1997; 25(6): 387-408.

25. Diana Wood F. Clinical Review. ABC of learning and teaching in medicine, Problem based learning. BMJ. 2003; 326(7384): 328-30.

26. Martin Bland J. Teaching statistics to medical students using problem-based learning: the Australian experience. BMC Medical Education 2004; 4(1): 31.

27. Bassir SH, Sadr-Eshkevari P, Amirikhorheh S, Karimbux NY. Problem-based learning in dental education: a systematic review of the literature. J Dent Educ. 2014 Jan; 78(1): 98-109.

28. Matsuka $\mathrm{Y}$, Nakajima R, Miki $\mathrm{H}$, Kimura A, Kanyama M, Minakuchi $\mathrm{H}$, et al. A problem-based learning tutorial for dental students regarding elderly residents in a nursing home in Japan. J Dent Educ. 2012; 76(12): 1580-8.

29. Choi E, Lindquist $R$, Song Y. Effects of problem-based learning vs. traditional lecture on Korean nursing students' critical thinking, problem-solving, and self-directed learning. Nurse Edu. Today. 2014; 34(1): 52-6.

30. Tiwari A, Lai P, So M, Yuen K. A comparison of the effects of problem-based learning and lecturing on the development of students' critical thinking. Med Educ. 2006 Jun; 40(6): 547-54.

31. In-Soo Shin, Jung-Hee Kim. The effect of problem-based learning in nursing education: a meta-analysis. Advances in Health Sciences Education 2013: 18(5): 1103-20.
32. Weihua Zhang. Problem based learning in nursing education. Advances in Nursing 2014; (2014): 1-5.

33. Yusof M, Tasir Z, Haron J, Syed Ahmad Helmi Syed Hassan. Promoting problem-based learning in engineering courses at UniversitiTeknologi Malaysia Khairiyahln: Asia Pasific Forum on Engineering and Technology Education September 2005; 1(5): 26-9.

34. Polanco R, Calderon P, Delgado F. Problem based learning in engineering students: Its effects on academic and attitudinal outcomes. In: The power of problem-based learning. Little P., Kandlbinder P. Editors; 2001. 111-25.

35. Sato A, Morone M, Azuma Y. Effects of implementation of problem-based learning tutorials on fifth-year pharmacy students and future issues. Yakugaku Zasshi. 2011; 131(9): 1369-82.

36. Tahir Mehmood K, Mohamed Azmi H, Sahibzada Tasleem R. A study assessing the impact of different teaching modalities for pharmacy students in a Cardio-Pulmonary Resuscitation (CPR) course. Saudi Pharmaceutical Journal 2013; 21(4): 375-8.

37. Usoa Busto, Kathryn Knight, Eva Janecek, Pearl Isaac and Karen Parker. A problem-based learning course for pharmacy students on alcohol and psychoactive substance abuse disorders. American Journal of Pharmaceutical Education 1994; 8(1): 55-60.

38. Nur IzzatiAbdullaha, Rohani Ahmad Tarmizia, Rosini Abub. The effects of problem based learning on mathematics performance and affective attributes in learning statistics at form four secondary level. International conference on mathematics education research 2010 (ICMER 2010) procedia-social and behavioral sciences 2010; 8(1): 370-6.

39. Newman M. Problem based learning: an introduction and overview of the key features of the approach. Journal of veterinary 2005; 32(1): 12-20

40. Wolff A. Problem based learning. The role of the tutor: A resource guide for faculty. Vancouver: Wolff Consulting; 2000.

41. Cindy E, Hmelo-Silver chmelosi, Howard Barrows S. Goals and strategies of a problem-based learning facilitator. IJPBL. 2006; 1(1): 21-39.

42. Woods DR, Hall FL, Eyles CH, Hrymak AN, Duncan-Hewitt WC. Tutored versus tutorless groups in problem-based learning. American journal of pharmaceutical education 1999; 60(3): 231-8.

43. Groves M, Rego PO, Rourke P. Tutoring in problem-based learning medical curricula: the influence of tutor background and style on effectiveness. BMC Med Educ. 2005; 5(1): 20.

44. Schmidt HG, Van der arend A, Moust JH, Kokx I, Boon L. Influence of tutors' subject-matter expertise on student effort and achievement in problem-based learning. Acad Med. 1993; 68(10): 784-91.

45. Wun YT, Tse EY, Lam TP, Lam CL. PBL curriculum improves medical students' participation in small-group tutorials. Med Teach. 2007 Sep; 29(6): 198-203.

46. Holen A. The PBL group: self-reflections and feedback for improved learning and growth. 2000; 22(5): 485-8.

47. Willis SC, Jones A, Bundy C, Burdett K, Whitehouse CR, O'Neill PA. Small-group work and assessment in a PBL curriculum: a qualitative and quantitative evaluation of student perceptions of the process of working in small groups and its assessment. Medical Teacher 2002; 24(5): 495-501.

48. Tipping J, Freeman RF, Rachlis AR. Using faculty and student perceptions of group dynamics to develop recommendations for PBL training. Acad Med. 1995; 70(11): 1050-2.

49. Abrandt Dahlgren M, Dahlgren LO. Portraits of PBL. students' experiences of the characteristics of problem-based learning in physiotherapy, computer engineering and psychology. Instructional Science 2002; 30(1): 111-27.

50. Schraw G. Promoting general metacognitive awareness. Instructional Science 1998; 26(1-2): 113-25.

51. Knowles MS. Self directed learning: a guide for learners and teachers. New York, Cambridge adult education; 1975.

52. Zimmerman BJ. Self-regulated learning and academic achievement: An overview. Educational Psychologist 1990; 25(1): 3-17.

53. Barrows HS. Problem-based learning in medicine and beyond: A brief overview. New directions for teaching and learning 1996; 1996(68): 3-12.

54. Barrett T. Understanding problem-based learning. In: Handbook of enquiry and problem-based learning. Barrett T., Labhrainn IM., Fallon H. Galway. Editors. Centre for Excellence in Learning and Teaching, NUI Galway; 2005: 13-25.

55. Larisa Ivo'n Carrera, Toma's Eduardo Tellez and Alberto Enrique D'Ottavio. Implementing a problem-based learning curriculum in an Argentinean medical school: Implications for developing countries. Academic medicine 2003; 78(8): 798-01 
56. Cesolari JAM, D'Ottavio AE, Zapata GO, Rossi AR, Villar IJ, Merli SA Factors with potential influence on early attrition during the first year of the medical career. Compensatory proposals. Medicina y Sociedad (Argentina). 1991; 14: 31-35.

57. Diana Dolmans HJM, HettySnellen Balendong, InekeWolfhagen HAP, Cess Van Der Vleuten PM. Seven principles of effective case design for a problem based curriculum. Medical teacher 1997; 3(19): 185-9.

58. Guide to problem-based learning - University of York. Available online from https://www.york.ac.uk/media/law/documents/pbl_guide.pdf.

59. Introduction to PBL at Hull York Medical School - Transcript. Available online from http://www.hyms.ac.uk/documents/UG/transcript.pdf.

60. Davis FB. Fundamental factors of comprehension of reading. Psychometrika. 1944; 9(3): 185-97.

61. Peter Afflerbach, David Pearson P, Scott Paris G. Clarifying differences between reading skills and reading strategies. The reading teacher 2008; 61(5): 364-73.

62. DejanBokonjic, MladenMimica, NurkaPranjic, VanjaFilipovic, SladanaCosovic, Hans-Martin Bosse, et al. Problem based learning. In. Manual of teaching and learning in medicine. Steiner T. and Sonntag HG., D. Bokonjic Editors. Available online from http://www.bhmed-emanual.org/ chapter_7_problem_based_learning.

63. Taiseer zaid kailani. Reading aloud in EFL revisited. Reading in foreign language1998; 12(1): 281-94.

64. Duursma E, Augustn M, Zuckerman B. Reading aloud to children: the evidence. Arch Dis Child. 2008; 93(7): 554-557.

65. UdenBeumont. Appendix 7 A. PBL Case: Requirement analysis technology and problem-based learning. In: Technology and problem based learning. Ed. Uden L. Information science publishing. Hershey PA; 2008: 147-8.

66. Savery JR., Duffy TM. Problem based learning: An instructional model and its constructivist framework. Educational Technology 1994; 34(8): 135-150

67. Pamela Pastirik J. Using problem-based learning in a large classroom. Nurse Education in Practice. 2006; 6(5): 261-7.

68. Willie Yip. Students' perceptions of the technological supports for problembased learning. Education and Information Technologies 2002; 7(4): 303-12.

69. 69. Hideyuki Kanematsu, Yoshimi Fukumura, Dana Barry M, So Young Sohn, Ryosuke Taguchi, Nunez Rattia Rodrigo Arturo. Conversation analysis of $\mathrm{PBL}$ in metaverse for students from the USA, Korea and Japan. International Conference on Engineering Education ICEE-2010. July 18-22, 2010, Gliwice, Poland . 1-5

70. Jill Riley, Ruth Matheson. Problem based learning in health and social care In: Promoting creative thinking and innovative practice through the use of problem-based learning. Ed. Teena J. Clouston, Lyn Westcott, Steven Whitcombe W., Jill Riley, Ruth Matheson. 2010. Wiley Blackwell. 125-38.

71. Larmer John, John Mergendoller R. Seven essentials for project-based learning giving students meaningful work. Giving students meaningful work 2010; 68(1): 34-7.

72. Charles Harris I, GulGuner A, James Arbogast, Lisa Salati B, James Shumway M. Integrated problem based learning for first year medical students: does it teach biochemical principles?. Biochemical education 1997; 25(3): 146-50.

73. Kinnunen Palvi, MalmiLauri. Problems in problem-based learning experiences, analysis and lessons learned on an introductory programming course. Informatics in Education 2005; 4(2): 193-214.

74. Donovan G, Cluer J. 100 Lessons from self managed work teams. Perth, Australia: SMWTGN; 1994

75. Kindler HS. Understanding Conflict management. In: Managing disagreement constructively. Los Altos, Canada: Crisp publications; 1988. 2-22.

76. Michael Peterson. Skills to enhance problem-based learning. Med Educ Online; 1997. 2,3. Available from: URL http://www.utmb.edu/meo/

77. Edwin Bridges, Phillip Hallinger. Using problem based learning to prepare educational leaders. Pedagogy journal of education 1997; 72(2): 131-46.

78. Peterson M. A team-based approach to problem based learning: An evaluation of structured team problem solving. Journal on Excellence in College Teaching 1996; 7(3): 129-53.

79. Peterson M. Effectiveness of a team-based approach among students in a teacher preparation course. University of Delaware, Center for teaching effectiveness 1997; 40(6): 1369-97.

80. Sheive L, Metivier LG. A participant's guide to STePS. EDITORS. $4^{\text {th }}$ ed Baldwinsville, NY: STePS Associates; 1994.

81. Nevo D. The conceptualization of educational evaluation: an analytical review of the literature. In: New Directions in Educational Evaluation. House ER Editors 1986, Palmer Press, Lewes. 15- 29.

82. Das M, Mpofu D, Dunn E, Lanphear JH. Self and tutor evaluations in problem based learning tutorials: is there a relationship?. Medical education 1998 32(4): 411-8.

83. Rosamaria Valle, Ileana Petra, Adrian Martinez Gonzalez, Jose Antonio Rojas-Ramirez, Sara Morales-Lopez, Beatriz Pina-Garza. Assessment of student performance in problem-based learning tutorial sessions. Medical education 1999; 33(11): 818-22.

84. Tai, Gillian Xiao-Lian and Yuen, May Chan. Authentic assessment strategies in problem based learning. Proceedings ascilite Singapore; 2007. 983-93. 